\title{
Comparison of various procedures in the processing of binucleated- lymphocytes on to glass slide to detect chromosomal breakage
}

\author{
Jeanne Adiwinata Pawitan,* Isnani Azizah Suryono,* Lia Damayanti,* Sigit Purbadi,**
}

\begin{abstract}
Abstrak
Sediaan limfosit berinti dua diperlukan untuk mendeteksi patah kromosom menggunakan uji mikronukleus. Uji mikronukleus dilakukan pada sel dengan sitoplasma utuh, dan memerlukan paling sedikit 800 sel utuh berinti dua. Ada berbagai prosedur pembuatan sediaan limfosit berinti dua yang berbeda dalam cara panen, fiksasi dan pembuatan sediaan. Penelitian ini bertujuan membandingkan berbagai prosedur dan berbagai modifikasinya untuk mendapatkan prosedur yang menghasilkan sel berinti dua utuh yang lebih banyak dengan hasil pewarnaan yang baik untuk uji micronucleus. Kami membandingkan berbagai prosedur (keseluruhan ada 17 macam prosedur) yang dilakukan pada 7 sampel darah yang berasal dari penderita keganasan yang berobat ke pav. E RIA, bagian kebidanan dan penyakit kandungan FKUI/RSUPN-CM, Jakarta. Ketujuhbelas prosedur tersebut berbeda dalam cara panen (dengan dan tanpa pencucian), pembuatan sediaan (cara usap, bercak, dan sitospin), dan fiksasi (methanol 1 menit, methanol siram, methanol:asam asetat glacial 3:1 atau 9:1). Analisis hasil menunjukkan bahwa fiksasi dengan methanol/asam asetat glacial memberi hasil pewarnaan yang tidak cocok untuk uji mikronukleus. Cara panen tanpa pencucian, pembuatan sediaan cara bercak atau menggunakan sitospin, dengan fiksasi methanol dan methanol siram, memberi hasil pewarnaan dan penyebaran sel yang optimal serta jumlah LIDU (limfosit inti dua) yang cukup. (Med J Indones 2003; 12: 3-7)
\end{abstract}

\begin{abstract}
Binucleated lymphocytes can be screened for micronuclei to assess chromosomal damage. There are various procedures to get slides containing binucleated lymphocytes, that are different in harvesting, fixation, and slide preparation methods. Screening binucleated lymphocytes to find a micronucleus needs at least 800 cells with intact cytoplasm. This study aimed to analyze the various procedures and simplified procedures to know which procedure gave the most abundant binucleated lymphocytes with intact cytoplasm and best staining properties for the purpose of micronucleus scoring. Seven heparinized blood samples were obtained from the Dept. of Obstetrics and gynecology, Faculty of medicine, University of Indonesia, Jakarta. The 7 blood samples were subjected to 17 procedures different in harvesting (with or without washing), slide preparation (smear and spot method, and using a cytocentrifuge), and fixation methods (methanol for 1 minute, methanol brief, methanol/glacial acetic acid 3:1 or 9:1). Our results showed that fixatives containing glacial acetic acid are not suitable for micronucleus test. To generate binucleated lymphocytes with intact cytoplasm as much as possible, the procedure should be conducted without washing steps. Methanol fixation either briefly or 1 minute is preferable, and for the ease of screening cytocentrifuge preparation, followed by spot method is preferable. (Med J Indones 2003; 12: 3-7)
\end{abstract}

Keywords: cytokinesis blocked, spot, smear, cytocentrifuge, fixatives

At present, one of the most promising methodologies to assess chromosomal damage (breakage and lost) is the micronucleus test on cytokinesis blocked lymphocytes. ${ }^{1}$ Many studies have been published using this methodology. ${ }^{2-8}$ The cytokinesis blocked (CB, binucleated) lymphocytes are generated by culturing peripheral blood lymphocytes in a medium containing

\footnotetext{
* Department of Histology, Faculty of Medicine, University of Indonesia, Jakarta, Indonesia

** Department of Obstetrics and Gynecology, Faculty of Medicine, University of Indonesia, Jakarta, Indonesia
}

serum and phytohemeagglutinin, with an addition of cytochalasin B after culturing 44 hours, and harvesting at hour 72 . The harvested binucleated lymphocytes are then mounted on to a glass slide. The procedure to mount on glass slide consists of various steps, i.e. washing; fixation and putting on glass slide, staining, and mounting. ${ }^{9}$ There are several ways to put the binucleated lymphocytes on a glass slide, i.e. drop, smear, and spot method, or by using a cytocentrifuge. Moreover, there are several ways of fixation, i.e. using pure methanol, Carnoy and modification of Carnoy solution (methanol/glacial acetic acid 3:1 and 5:1), and $1 \%$ glutaraldehyde in Sorensen buffer $\mathrm{pH}$ 6.8. ${ }^{9-11}$ 
Screening binucleated lymphocytes to find a micronucleus needs at least 800 cells with intact cytoplasm. ${ }^{11}$ One popular method, however, the drop method using fixative prior to dropping the suspension on to a glass slide generated too much acytoplasmic cells. ${ }^{10}$ There is no data to show which procedure give the most abundant binucleated lymphocytes with intact cytoplasm. Therefore, this study aimed to analyze the various procedures and simplified procedures to know which procedure gave the most abundant binucleated lymphocytes with intact cytoplasm and best staining properties for the purpose of micronucleus scoring.

\section{METHODS}

This study was a laboratory research, and conducted at the Department of Pathology (culture - harvestprocessing on to glass slide) and at the Department of Histology (staining, screening, and analysis), University of Indonesia, Jakarta, Indonesia, from September 1997 through June 2000. Ethical clearance was obtained from the committee of the medical research ethics of the Faculty of Medicine, University of Indonesia.

\section{Samples}

Seven heparinized blood samples were obtained from the Dept. of Obstetrics and Gynecology, Faculty of medicine, University of Indonesia. Blood samples were taken after the patients signed the informed consent.

\section{Materials}

RPMI 1640, phytohemeagglutinin (PHA), and penicillin/ streptomycin for culture were purchased from Giebco BRL, while human $\mathrm{AB}$ serum, DMSO, and cytochalasin-B from Sigma. In addition, methanol, glacial acetic acid, chemicals (proanalysi), and Giemsa stock solution were purchased from Merck.

\section{Procedures}

Blood plasma $(0.5 \mathrm{ml})$ was taken soon after the erythrocytes were subjected to gravity sedimentation. Then the plasma was washed in RPMI 1640, and the pellet was cultured in $10 \mathrm{ml}$ medium at $37{ }^{\circ} \mathrm{C}$ for 44 hours. At the end of the 44 hours, cytochalasin-B diluted in DMSO and phosphate buffered saline $\mathrm{pH} 7$ (final concentration $3 \mu \mathrm{g} / \mathrm{ml}$ ) was added, and the culture was continued until 72 hours. After 72 hours the cells were harvested and processed using 17 processing procedures (published procedures and simplified modifications) on to glass slides. The slides were stained, and screened. The results of the 17 procedures were analyzed.

\section{Culture medium}

For each culture, the culture medium $(10 \mathrm{ml})$ contained $8.5 \mathrm{ml}$ RPMI 1640, $1.5 \mathrm{ml}$ human $\mathrm{AB}$ serum, $100 \mu \mathrm{l}$ phytohemeagglutinin (PHA), and $100 \mu \mathrm{l}$ penicillin/ streptomycin (containing 10,000 U /10,000 $\mu \mathrm{g}$ ).

\section{Harvesting, processing and staining procedures}

At the end of 72 hours, $2 \times 0.5 \mathrm{ml}$ of the culture were used to make cytocentrifuge preparations of the cells on clean glass slides (110 rpm, 10 minutes). The cells were fixed in pure methanol for 1 minute, and stained in $5 \%$ Giemsa solution $\mathrm{pH} 6.8$ for 15 minutes. The rest was processed according to 16 different procedures depicted in table 1, and stained in $5 \%$ Giemsa solution for 5 minutes.

Table 1. Harvesting and processing procedures

\begin{tabular}{lllll}
\hline \multirow{2}{*}{ Procedure } & \multirow{2}{*}{ Washing } & \multirow{2}{*}{$\begin{array}{l}\text { Slide } \\
\text { preparation }\end{array}$} & Fixative & Duration \\
\cline { 4 - 5 } & & & Fixation \\
\hline 1 & Yes & Spot & Pure meOH & Briefly \\
2 & Yes & Spot & Pure meOH & 1 min. \\
3 & Yes & Spot & meOH/HAc 3:1 & Briefly \\
4 & Yes & Spot & meOH/HAc 9:1 & Briefly \\
5 & Yes & Smear & Pure meOH & Briefly \\
6 & Yes & Smear & Pure meOH & 1 min. \\
7 & Yes & Smear & meOH/HAc 3:1 & Briefly \\
8 & Yes & Smear & meOH/HAc 9:1 & Briefly \\
9 & No & Spot & Pure meOH & Briefly \\
10 & No & Spot & Pure meOH & 1 min. \\
11 & No & Spot & meOH/HAc 3:1 & Briefly \\
12 & No & Spot & meOH/HAc 9:1 & Briefly \\
13 & No & Smear & Pure meOH & Briefly \\
14 & No & Smear & Pure meOH & 1 min. \\
15 & No & Smear & meOH/HAc 3:1 & Briefly \\
16 & No & Smear & meOH/HAc 9:1 & Briefly \\
\hline
\end{tabular}

$\mathrm{meOH}=$ pure methanol, $\mathrm{HAc}=$ glacial acetic acid, spot and smear $=$ methods of putting cells on to glass slide ${ }^{2}$

\section{Slide analysis and screening}

The slides were analyzed for the staining results and cell distribution, and screened for the percentage of binucleated cells and acytoplasmic binucleated cells (a total of 100 cells were screened). 


\section{Data analysis}

The results of the 17 procedures were noted. A slide that gave clear distinction between nucleus and cytoplasm (nucleus stained darker than cytoplasm) and the cells were evenly distributed was regarded as having a good staining and cell distribution result.

The percentage of binucleated cells and acytoplasmic binucleated cells were analyzed and the mean and range for each procedure were tabulated. To see whether there were significant differences in the percentage of binucleated cells and acytoplasmic binucleated cells, comparisons between procedures 117 were done using one way ANOVA In addition, comparison between procedures 1-16 were done using univariate ANOVA (SPSS 10.0.0 for Windows $98 / 2000 / \mathrm{NT}),{ }^{12}$ to see the effect of washing, slide preparation, and fixation, where the dependent variable was the percentage of intact or acytoplasmic binucleated cells, and the fixed variables were washing, slide preparation, and fixation.

\section{RESULTS}

Some samples gave not enough cells when cultured, so that some procedures were omitted for those samples. In addition, some of the procedures gave poor processing and staining result, so that screening of cells could not be done, due to invisible nucleus/ nuclei or there was no cell seen. The procedures done for each of the 7 samples and the result of processing and staining were depicted in table 2 .

\section{Staining results}

According to the fixative used, the percentage of slides that gave poor staining result was depicted in Table 3. The cytospinned slides fixed in methanol for 1 minute gave the best staining, showing a clearly seen nucleus/nuclei and pale blue evenly stained cytoplasm, while fixatives containing glacial acetic acid tended to give poor results, where the cytoplasm was stained darker than the nucleus/nuclei, or the nucleus was invisible. Spot and smear method showed about the same staining results. The procedure without washing step showed same staining properties compared with the procedures with a washing step. Regarding cell size, cytospinned slides showed the biggest size, followed by smear and spot method.

Table 3. The percentage of slides with poor staining result according to the fixative used

\begin{tabular}{lc}
\hline Fixative & Poor staining (\%) \\
\hline meOH/HAc $3: 1$ & 46 \\
meOH/HAc $9: 1$ & 30 \\
meOH brief & 4 \\
meOH 1 minute & 5 \\
meOH 1 minute -cytospinned & 0 \\
\hline
\end{tabular}

Table 2. The procedures done for each sample and the result

\begin{tabular}{|c|c|c|c|c|c|c|c|}
\hline Procedure & $\begin{array}{l}\text { Sample1 } \\
\text { / result }\end{array}$ & $\begin{array}{l}\text { Sample2 } \\
\text { / result }\end{array}$ & $\begin{array}{l}\text { Sample3 } \\
\text { / result }\end{array}$ & $\begin{array}{l}\text { Sample4 } \\
\text { / result }\end{array}$ & $\begin{array}{l}\text { Sample5 } \\
\text { / result }\end{array}$ & $\begin{array}{l}\text { Sample6 } \\
\text { / result }\end{array}$ & $\begin{array}{l}\text { Sample7 } \\
\text { / result }\end{array}$ \\
\hline 1 & $\mathrm{~N}$ & $\mathrm{Y} /+$ & $\mathrm{Y} /+$ & $\mathrm{Y} / \pm$ & $\mathrm{Y} /+$ & $\mathrm{Y} /+$ & $\mathrm{Y} /+$ \\
\hline 2 & $\mathrm{Y} /+$ & $\mathrm{N}$ & $\mathrm{N}$ & $\mathrm{Y} /+$ & $\mathrm{Y} /+$ & $\mathrm{Y} /+$ & $\mathrm{Y} /+$ \\
\hline 3 & $\mathrm{Y} /+$ & $\mathrm{Y} /+$ & $\mathrm{Y} / \pm$ & $\mathrm{Y} / \pm$ & Y/- & $\mathrm{Y} /+$ & $\mathrm{Y} /+$ \\
\hline 4 & $\mathrm{Y} / \mathrm{F}$ & $\mathrm{Y} /+$ & $\mathrm{Y} /+$ & $\mathrm{Y} /+$ & $\mathrm{Y} /+$ & Y/- & $\mathrm{Y} /+$ \\
\hline 5 & $\mathrm{~N}$ & $\mathrm{Y} /+$ & $\mathrm{Y} /+$ & $\mathrm{Y} /+$ & $\mathrm{Y} /+$ & $\mathrm{Y} /+$ & $\mathrm{Y} /+$ \\
\hline 6 & $\mathrm{Y} /+$ & $\mathrm{N}$ & $\mathrm{N}$ & $\mathrm{Y} / \pm$ & Y/+ & $\mathrm{Y} /+$ & $\mathrm{Y} /+$ \\
\hline 7 & $\mathrm{~N}$ & $\mathrm{Y} /+$ & Y/- & $\mathrm{Y} /+$ & $\mathrm{N}$ & Y/- & $\mathrm{Y} /+$ \\
\hline 8 & $\mathrm{Y} /+$ & $\mathrm{Y} /+$ & $\mathrm{Y} /+$ & $\mathrm{Y} / \pm$ & $\mathrm{Y} /+$ & $\mathrm{Y} / \pm$ & $\mathrm{Y} / \pm$ \\
\hline 9 & $\mathrm{Y} /+$ & $\mathrm{Y} /+$ & $\mathrm{Y} /+$ & $\mathrm{Y} /+$ & $\mathrm{Y} /+$ & $\mathrm{Y} /+$ & $\mathrm{Y} /+$ \\
\hline 10 & $\mathrm{Y} /+$ & $\mathrm{N}$ & $\mathrm{Y} /+$ & $\mathrm{Y} /+$ & $\mathrm{Y} /+$ & $\mathrm{Y} /+$ & $\mathrm{Y} /+$ \\
\hline 11 & $\mathrm{Y} /+$ & Y/- & $\mathrm{Y} / \mathrm{F}$ & $\mathrm{Y} / \pm$ & $\mathrm{Y} /+$ & $\mathrm{Y} / \pm$ & $\mathrm{Y} /+$ \\
\hline 12 & $\mathrm{Y} /+$ & $\mathrm{Y} / \pm$ & $\mathrm{Y} / \pm$ & $\mathrm{Y} / \pm$ & $\mathrm{Y} /+$ & $\mathrm{Y} /+$ & $\mathrm{Y} /+$ \\
\hline 13 & $\mathrm{Y} /+$ & $\mathrm{Y} /+$ & $\mathrm{Y} / \mathrm{F}$ & $\mathrm{Y} /+$ & $\mathrm{Y} /+$ & $\mathrm{Y} /+$ & $\mathrm{Y} /+$ \\
\hline 14 & $\mathrm{Y} /+$ & $\mathrm{N}$ & Y/+ & $\mathrm{Y} /+$ & $\mathrm{Y} /+$ & $\mathrm{Y} /+$ & $\mathrm{Y} /+$ \\
\hline 15 & $\mathrm{Y} /+$ & $\mathrm{Y} /+$ & $\mathrm{Y} /+$ & $\mathrm{Y} / \pm$ & $\mathrm{Y} /+$ & $\mathrm{Y} / \pm$ & $\mathrm{Y} / \pm$ \\
\hline 16 & $\mathrm{Y} /+$ & $\mathrm{Y} /+$ & $\mathrm{Y} /+$ & $\mathrm{Y} /+$ & $\mathrm{Y} /+$ & $\mathrm{Y} / \pm$ & $\mathrm{Y} /+$ \\
\hline cytospin & $\mathrm{Y} / \mathrm{F}$ & $\mathrm{Y} / \mathrm{F}$ & $\mathrm{Y} / \mathrm{F}$ & $\mathrm{Y} /+$ & $\mathrm{Y} /+$ & $\mathrm{Y} /+$ & $\mathrm{Y} /+$ \\
\hline
\end{tabular}

$\mathrm{Y}=$ procedure done, $\mathrm{N}=$ procedure not done, $\mathrm{F}=$ failure (no cell was seen), $(+)=$ good staining result, $( \pm)=$ poor staining result, still possible to screen, $(-)=$ poor staining result, impossible to screen 


\section{Cell distribution}

Smeared cells generally showed wide distribution, and a tendency to gather at the end of the slide. Spot method showed evenly distributed cells in a restricted area, and cytospinned slides showed densely distributed cells in a very small area. For screening purposes, the cytospinned slides were the most easily screened. However, failure to find visible cells with good staining (clearly seen nucleus/nuclei) happened in 2, 4 and $42 \%$ of the slides that were made using the smear, spot and cytospinned methods, respectively.

\section{Binucleated cells}

The percentage of binucleated cells among all cells (mononucleated, binucleated, and cells with three, four, or more nuclei) for each procedure is showed in Table 4. Our results showed that the procedure without washing step gave more binucleated cells compared to the methods with a washing step, and the difference was statistically significant $(P=.01)$.

\section{Intact binucleated cells}

The percentage of intact binucleated cells among all binucleated cells for each procedure is showed in Table 5. Our results showed that the procedure without washing step gave more intact binucleated cells compared to the methods with a washing step, except for the spot method using methanol/glacial acetic acid 3:1 as fixative, and the difference was statistically significant $(P=.007)$

\section{DISCUSSION}

In three slides that were processed according to procedure 4, 11, and 13, and in another 3 slides that were processed using cytocentrifuge (Table 2), we failed to find a cell. Procedure 4, 11, and 13 gave each 1 failure out of the 7 samples, while slide preparation using cytocentrifuge gave 3 failures out of the 7 samples. In procedure 4 and 11, the cells were put on to the slides using the spot method, while in procedure 13, smear method was used (Table 1). All together, the smear, spot, and cytocentrifuge method gave a failure of 1 out of 50, 2 out f 52, and 3 out of 7 slides, respectively (Table 2). Therefore, slide preparation using cytocentrifuge gave the most failure, followed by spot and smear method. However, screening in a restricted area is more easy, and is more suitable when image analysis device is used..$^{10}$ Therefore, for the ease of screening, the most easy to screen were the slides prepared using cytocentrifuge, followed by spot and smear method, as the area to be screened was smallest in slides prepared by cytocentrifuge.

Table 4. The percentage of binucleated cells in the various procedures

\begin{tabular}{|c|c|c|c|c|c|}
\hline $\begin{array}{l}\text { Slide } \\
\text { preparation }\end{array}$ & xative & $\begin{array}{l}\mathrm{meOH} / \mathrm{Hac} \\
3: 1\end{array}$ & $\begin{array}{l}\mathrm{meOH} / \mathrm{Hac} \\
9: 1\end{array}$ & $\begin{array}{l}\text { meOH } \\
\text { brief }\end{array}$ & $\begin{array}{l}\text { meOH } \\
1 \text { minute }\end{array}$ \\
\hline Smear & $(+)$ & 9.3 & 16.9 & 14.8 & 13.2 \\
\hline \multirow{3}{*}{ Spot } & $(-)$ & 23.7 & 23.4 & 20.5 & 17.8 \\
\hline & $(+)$ & 13.5 & 14.8 & 15.5 & 11 \\
\hline & $(-)$ & 16.4 & 19 & 15.7 & 16.2 \\
\hline Cytospinned & $(-)$ & & & & 14 \\
\hline
\end{tabular}

$\mathrm{meOH}=$ methanol, $\mathrm{HAc}=$ glacial acetic acid

Table 5. The percentage of intact binucleated cells in the various procedures

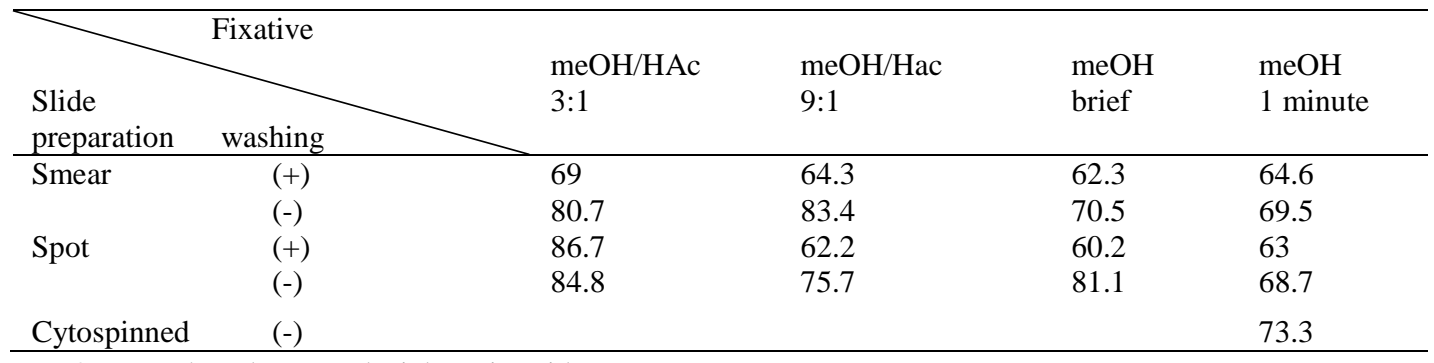

$\mathrm{meOH}=$ methanol, $\mathrm{Hac}=$ glacial acetic acid 
Screening cells for micronuclei needs clearly distinguishable nucleus/nuclei from the cytoplasm, as micronuclei have the same staining properties as the nucleus/nuclei, and should be searched in the cytoplasm. ${ }^{13}$ Fixative containing glacial acetic acid tended to give darkly stained cytoplasm (Table 3), so that it was difficult to see the nucleus, and in some cases the nucleus was indistinguishable from the cytoplasm. Formerly, fixative containing glacial acetic acid was used to cause lysis of erythrocytes in whole blood culture. Methanol fixation was regarded not ideal for micronucleus screening, since a large number of erythrocytes were still present in the background. ${ }^{12}$ However, in this study, methanol fixation gave better staining results compared to fixative containing glacial acetic acid.

Washing step is usually done in the preparation of binucleated lymphocytes. ${ }^{9,10}$ However, in a study, slide preparation using cytocentrifuge was without any washing step. ${ }^{11}$ In this study, the procedure without washing step gave more binucleated cells compared to the methods with a washing step. In addition, the procedure without washing step gave more intact binucleated cells compared to the methods with a washing step, except for the spot method using methanol/glacial acetic acid 3:1 as fixative. It seems that a fixative containing glacial acetic acid caused more acytoplasmic cells. Therefore, washing steps, especially when it is not conducted gently tend to cause cell lost and acytoplasmic cells.

Slide preparation using cytocentrifuge (fixed by methanol for 1 minute) gave the biggest cell size, so it was easier to screen the cells for micronucleus. This fact might be due to the pressure endured by the cells during centrifugation. In this study, the cells obtained by spot method were smaller compared to those obtained by smear method, and this fact is in line with the findings of another study. This fact should be taken into account, when screening is done using an image analyzer. ${ }^{10}$

In conclusion, to generate binucleated lymphocytes with intact cytoplasm as much as possible, the procedure should be conducted gently and with the minimal steps possible (without washing steps). Methanol fixation either briefly or 1 minute is preferable, and for the ease of screening cytocentrifuge preparation, followed by spot method is preferable. However, skill in making cytocentrifuge preparation is needed to avoid failure.

\section{Acknowledgements}

The authors would like to thank the paramedics of the Department of Obstetrics and Gynecology, Faculty of Medicine, University of Indonesia, Jakarta for their help in taking the blood samples, and the patients who have participated in this study. This study was funded by the Risbin Iptekdok II research grant from the Indonesian Institute of Sciences (LIPI).

\section{REFERENCES}

1. Kirsch-Volders M, Fenech M. Inclusion of micronuclei in non-divided mononuclear lymphocytes and necrosis/ apoptosis may provide a more comprehensive cytokinesis block micronucleus assay for monitoring purposes. Mutagenesis 2001;16(1):51-8.

2. Lee TK, Allison RR, O'Brien KF, Naves JL, Karlsson UL, Wiley Al. Persistence of micronuclei in lymphocytes of cancer patients after radiotherapy. Radiat Res 2002;157(6):678-84.

3. Santos-Mello R, Deimling LI, Lauer Junior CM, Almeida A. Induction of micronuclei by alkaloids extracted from Senecio braciliensis and stored for 23 years. Mutat Res 2002;516(1-2):23-8.

4. Maluf SW, Passos DF, Bacelar A, Speit G, Erdtmann B. Assessment of DNA damage in lymphocytes of workers exposed to X-radiation using the micronucleus test and the comet assay. Environ Mol Mutagen 2001;38(4):311-5.

5. Ibrulj S, Duricic E. Genotoxicity of oxazepam-the micronucleus cytochalasin-B test. Med Arh 2002;56(2):61-4. (Abstract)

6. Pitarque M, Vaglenov A, Nosko M, Pavlova S, Petkova V, Hirvonen A, et al. Sister chromatid exchange and micronuclei in peripheral lymphocytes of shoe factory workers exposed to solvents. Environ Health Perspect 2002;110(4):399-404.

7. Leal-Garza CH, Cerda Flores RM, Leal-Elizondo E, CortezGutierrez EI. Micronuclei in cervical smears and peripheral blood lymphocytes from women with and without cervical uterine cancer. Mutat Res 2002;515(1-2):57-62.

8. Tice RR, Hook GG, Donner M, McRee DI, Guy AW. Genotoxicity of radiofrequency signals. I. Investigation of DNA damage and micronuclei induction in cultured human blood cells. Bioelectromagnetics 2002;23(2):113-26.

9. Tawn EJ, Holdsworth D. Mutagen-induced chromosome damage in human lymphocytes. In: Rooney DE, Czepulkowski BH, editors. Human cytogenetics. Vol 2. Malignancy and acquired abnormalities. A practical approach. Oxford:Oxford;1992. p.189-208.

10. Castelain P, van Hummelen P, Deleener A, KirschVolders M. Automated detection of cytochalasin-B blocked binucleated lymphocytes for scoring micronuclei. Mutagenesis 1993;8(4):285-93.

11. Fenech M, Morley AA. Measurement of micronuclei in lymphocytes. Mutat Res 1985;147:29-36.

12. SPSS 10.0.1 for Windows 98/2000/NT [computer program]. SPSS Inc 1999. www.spss.com

13. Hogstedt B. Micronuclei in lymphocytes with preserved cytoplasm. A method for assessment of cytogenetic damage in man. Mutat Res 1984;130:63-72. 
